\title{
Correlation of misperceptions in Turkish nurses' knowledge regarding HIV and their attitude toward patients with HIV/AIDS
}

\author{
Ayşegül KOÇ, Dilek ÖZTAŞ², Erdal CEYLAN ${ }^{1}$
}

\footnotetext{
${ }^{1}$ Department of Nursing, Ankara Yıldırım Beyazıt University, Faculty of Health Sciences, Ankara, Turkey.

2 Department of Public Health, Ankara Yıldırım Beyazıt University, Medical School, Ankara, Turkey.
}

\section{SUMMARY}

Human immunodeficiency virus/acquired immune deficiency syndrome (HIV/AIDS) cases have been increasing in Turkey, in line with global trends. This study aimed to determine whether nurses' knowledge regarding HIV/AIDS transmission gave rise to their attitude toward patients with HIV/AIDS and resulted in any patient discrimination.

This cross-sectional study included 164 nurses from the Yozgat State Hospital, Turkey. A demographic features form, an HIV/AIDS information form, and the AIDS Attitude Scale were used. Analysis of variance and t tests were used for statistical analyses.

The included nurses were both misinformed and inadequately informed about AIDS transmission. More than half of the nurses believed that foams, sponges, and diaphragms were prophylactics, while one third believed that intrauterine devices and birth control pills were prophylactics for HIV/AIDS. Nurses with graduate and undergraduate education had higher levels of knowledge regarding AIDS than did nurses with high school education. The subscales of the AIDS Attitude Scale showed correlations between fear of contagion and negative feelings (intermediate correlation), fear of contagion and professional resistance (weak correlation), and professional resistance and negative feelings (weak correlation).

Nurses had insufficient and incorrect knowledge of HIV transmission and prophylactic methods, leading to a negative attitude toward patients with AIDS/HIV.

Key words: Attitude, HIV/AIDS, nurse, Turkey

\section{INTRODUCTION}

The human immunodeficiency virus (HIV) slowly destroys the immune system, making it difficult for the body to fight against diseases and infections. Opportunistic infections and their complications may consequently be fatal (1). Globally, 40 million people are currently living with HIV, with 95\% of cases in developing countries $(2,3)$. Nurses and laboratory workers are at greatest risk for this disease, regardless of the clinic in which they work. Because HIV is transmitted through the body fluids of the infected person (semen, vaginal secretions and blood) (4). HIV/acquired immune deficiency syndrome (AIDS) remains difficult for health care professionals to manage. A report on HIV/AIDS-related health workers revealed that 5378 nurses of people living with HIV (PLWH) acquired this virus during their employment period (5).

The transmission of HIV infection, thus far, in the health care sector is rarely proved $(6,7)$. However, the fear of HIV transmission among health care workers is extremely high (8). Between $52 \%$ and $66 \%$ of nurses refuse to work with PLWH, which is too high to be ignored. Furthermore, nurses are reluctant to provide care and undertake invasive interventions for such patients $(9,10)$. On many occasions, perceptions of nurses and the general population have been the same. For instance, phlebotomy nurses, regardless of protection methods, may also fear the transmission of HIV infection and associated feelings

\section{Correspondence:}

Ayşegül KOÇ

Ankara Yıldırım Beyazıt Üniversitesi, Sağlık Bilimleri Fakültesi, Hemşirelik Bölümü, Ankara, Türkiye.

e-mail: aysegulkocmeister@gmail.com 
of guilt (11). Studies have demonstrated that the negative and stigmatizing attitudes of the nurses toward PLWH stemmed from a lack of education (12). Moreover, health professionals refused to attend to HIV-positive individuals, including homosexuals and drug addicts, whose lifestyles were assessed differently, because of their negative attitudes toward these individuals and fear of contagion $(9,12,13,14,15)$. The Ministry of Health data of patients with AIDS in Turkey revealed that 1575 Turkish citizens suffered from this disease. Of these, 74 were carriers, while 1501 were ill. Most of the patients with HIV/AIDS in Turkey were reported to be foreigners. In Turkey, 323 male and 599 female patients had AIDS. The distribution of AIDS cases and carriers according to the transmission was as follows: homosexual/bisexual intercourse, drug addiction, homosexual/bisexual intercourse and narcotic drugs, hemophilia, transfusion, heterosexual intercourse, infected mothers' babies, nosocomial transmission, and unknown $(16,17)$.

The low socioeconomic level of PLWH in Turkey, in line with the global trend, gives rise to psychological problems. All of these factors may reflect on the negative attitudes and approaches of health workers and nurses, and these attitudes and refusal to provide care for PLWH may detract from the quality of care (17).

This study thus aimed to determine whether a correlation existed between the levels of knowledge of nurses regarding HIV/AIDS and their attitudes toward PLWH.

\section{MATERIALS AND METHODS}

An application, expressing the objective and instruments of the study, was made through Bozok University TOBB Health College in writing. The necessary legal consent for the study was obtained. Before the application, working nurses were provided with an oral explanation of the study's content and objective. The questionnaires were then administered to the study's voluntary participants. This study was conducted at the Yozgat State Hospital and involved nurses working in all internal surgical clinics. Individuals who refused to participate in the study or were on leave on the scheduled dates were excluded. Finally, 164 nurses were included in this study.
Yozgat is a province in Central Anatolia with a small population and a low socioeconomic level. The social structure is currently maintained based on traditional beliefs. As it is located at the junction of important highways and railways, the presence of a temporary migration bureau and a large number of people seeking employment abroad contributes to the rise of HIV/AIDS in the area (18).

\section{AIDS Attitude Scale}

Specificity and reliability studies of the AIDS Attitude Scale developed by Bliwise et al. (1991) were completed by Çimen et al. (2005) in Turkey. This AIDS Attitude Scale adapted from English to Turkish could be applied to all health workers and students to determine their attitudes toward PLWH $(19,20)$.

The AIDS Attitude Scale was a practical Likert-type scale consisting of 15 items, each with 6 choices. Thirteen questions were scored normally, and two questions (items 2 and 8) were scored in the reverse direction. The attitude score ranged from 1 to 90 , obtained by adding the scores for all the 15 items. This scale consisted of three subscales - fear of contagion (items 1-5, scores ranging 5-30), negative feelings (items 6-9, scores 4-24), and professional resistance (items 10-15, scores 6-36). Higher total and subscale scores indicated a negative attitude toward PLWH (19). Cronbach's alpha was 073 in terms of the reliability of the study group.

\section{Nurses Knowledge regarding HIV/AIDS}

A 33-item questionnaire was prepared with the purpose of quantifying nurses' knowledge regarding HIV/AIDS — 11 items regarding transmission, 6 items regarding how it is not transmitted, 8 items regarding the body liquids that contain HIV, and 8 items regarding the AP methods as prophylaxis (21).

A correct answer for each item was accorded 1 point. The score for knowledge was quantified based on the number of questions answered correctly. The arithmetic means of the total knowledge score and the subscale scores were calculated.

Data Analysis

SStatistical methods appropriate for each question were chosen for data analysis, and SPSS and Microsoft Excel 2000 were used 
for statistical processing. Percentile distribution, means, and independent samples $t$ test were used for data assessment.

\section{Ethical Procedures}

Prior to the study, the consent necessary by law for the study was obtained. Moreover, the study objectives and methods were explained to the nurses working in the surgical clinics. Questions from the nurses during the data collection period were answered. The study was completed with voluntary participants.

\section{RESULTS}

The age distribution of the nurses was as follows: $18-25$ years (18.3\%), 26-33 years (49.4\%), and 33 years and over (32.3\%). Their educational levels were as follows: graduates of health vocational high school (29.9\%), associate degrees (42.1\%), and undergraduate degrees (28\%). Their durations of working in clinics were as follows: $0-5$ years of service $(23.2 \%), 6-10$ years, (34.1\%), 11-15 years (30.5\%), and 16 years and over (12.2\%). Fourteen percent of nurses were unmarried, while $86 \%$ were married (Table 1).

The mean of the total scores of the nurses on the AIDS Attitude Score was $64.53 \pm 8.03$ (22-75), while their mean score on the fear of contagion subscale was $13.41 \pm 3.66$ (8-30). Their mean score on the negative feelings subscale and professional resistance subscale was $9.09 \pm 3.01(4-22)$ and $15.05 \pm 3.88(8-32)$, respectively (Table 2). The mean score of the nurses on the AIDS Attitude Scale and the mean of all subscales based on their sociodemographic features were statistically insignificant $(P>0.05)$.

TABLE 1: Comparison of characteristics of nurses including means from the AIDS Attitude Scale and subscales.

\begin{tabular}{|c|c|c|c|c|c|}
\hline Features & $\begin{array}{c}n=164 \\
n(\%)\end{array}$ & $\begin{array}{l}\text { AIDS Attitude scale } \\
\qquad X \pm S S\end{array}$ & $\begin{array}{c}\text { Fear of contagion } \\
\qquad \pm \pm S S\end{array}$ & $\begin{array}{c}\text { Negative feelings } \\
\quad X \pm S S\end{array}$ & $\begin{array}{l}\text { Professional resistance } \\
\qquad X \pm S S\end{array}$ \\
\hline \multicolumn{6}{|l|}{ Age } \\
\hline $18-25$ years & $30(18.3)$ & $53.6 \pm 7.0$ & $18.9 \pm 4.0$ & $15.6 \pm 2.6$ & $19.0 \pm 2.9$ \\
\hline 26-33 years & $81(49.4)$ & $57.3 \pm 6.8$ & $20.2 \pm 3.3$ & $16.4 \pm 2.6$ & $20.6 \pm 3.9$ \\
\hline 34 and above & $53(32.3)$ & $54.9 \pm 9.7$ & $19.1 \pm 3.8$ & $15.6 \pm 3.6$ & $20.1 \pm 4.1$ \\
\hline Significance & & $\begin{array}{l}F=.564 \\
P>0.05\end{array}$ & $\begin{array}{l}F=.829 \\
P>0.05\end{array}$ & $\begin{array}{l}F=.265 \\
P>0.05\end{array}$ & $\begin{array}{l}F=1.120 \\
P>0.05\end{array}$ \\
\hline \multicolumn{6}{|l|}{ Educational status } \\
\hline \multirow{2}{*}{$\begin{array}{l}\text { Vocational health } \\
\text { high school }\end{array}$} & 49 (29.9) & $55.6 \pm 7.0$ & $19.4 \pm 3.6$ & $16.0 \pm 2.6$ & $20.1 \pm 3.6$ \\
\hline & 69 (42.1) & $56.5 \pm 7.9$ & $19.9 \pm 3.5$ & $16.3 \pm 3.0$ & $20.2 \pm 3.9$ \\
\hline Undergraduate & $46(28.0)$ & $55.1 \pm 9.1$ & $19.2 \pm 3.8$ & $15.7 \pm 3.3$ & $20.1 \pm 4.1$ \\
\hline Significance & & $\begin{array}{c}F=3.120 \\
P>0.05\end{array}$ & $\begin{array}{l}F=.553 \\
P>0.05\end{array}$ & $\begin{array}{c}F=4.294 \\
P>0.05\end{array}$ & $\begin{array}{l}F=.237 \\
P>0.05\end{array}$ \\
\hline \multicolumn{6}{|l|}{ Marital status } \\
\hline Married & $141(86.0)$ & $56.1 \pm 7.9$ & $19.7 \pm 3.6$ & $16.1 \pm 3.0$ & $20.2 \pm 3.8$ \\
\hline Unmarried & $23(14.0)$ & $54.1 \pm 8.5$ & $19.0 \pm 3.9$ & $15.2 \pm 3.0$ & $19.8 \pm 4.1$ \\
\hline Significance & & $\begin{array}{l}F=.955 \\
P>0.05\end{array}$ & $\begin{array}{l}F=.163 \\
P>0.05\end{array}$ & $\begin{array}{l}F=.271 \\
P>0.05\end{array}$ & $\begin{array}{l}F=.449 \\
P>0.05\end{array}$ \\
\hline \multicolumn{6}{|l|}{ Length of service } \\
\hline 5 years and below & $38(223.2)$ & $54.6 \pm 6.9$ & $19.2 \pm 3.4$ & $15.7 \pm 2.4$ & $19.9 \pm 3.5$ \\
\hline $6-10$ years & $56(34.1)$ & $56.8 \pm 6.8$ & $20.1 \pm 3.3$ & $16.4 \pm 2.6$ & $20.2 \pm 4.0$ \\
\hline $11-15$ years & $50(30.5)$ & $56.2 \pm 8.5$ & $19.5 \pm 4.1$ & $16.4 \pm 3.2$ & $20.2 \pm 3.5$ \\
\hline 16 years and above & $20(12.2)$ & $54.0 \pm 11.2$ & $19.1 \pm 3.8$ & $14.4 \pm 3.7$ & $20.4 \pm 4.8$ \\
\hline Significance & & $\begin{array}{c}F=4.052 \\
P>0.05\end{array}$ & $\begin{array}{l}F=.582 \\
P>0.05\end{array}$ & $\begin{array}{c}F=3.801 \\
P>0.05\end{array}$ & $\begin{array}{c}F=1.992 \\
P>0.05\end{array}$ \\
\hline
\end{tabular}


TABLE 2: Scores of nurses on the AIDS Attitude Scale and subscores.

\begin{tabular}{llll}
\hline AIDS Attitude Scale and subscores & Mean \pm SS & Minimum & Maximum \\
AIDS Attitude Scale score (15-90) & $64.53 \pm 8.03$ & 22 & 75 \\
Fear of contagion subscale score (5-30) & $13.41 \pm 3.66$ & 8 & 30 \\
Negative feelings subscale score (4-24) & $9.09 \pm 3.01$ & 4 & 22 \\
Professional resistance subscale score (6-36) & $15.05 \pm 3.88$ & 8 & 32
\end{tabular}

The majority of nurses (99.4\%) knew that HIV could be transmitted through blood and blood products to people not infected with HIV, while $41.5 \%$ believed that HIV could be transmitted through mosquito/insect bites. Moreover, $81.7 \%$ thought that HIV/AIDS was a hereditary transitional disease. Nearly half of the nurses thought that HIV was present in body liquids, such as bronchial fluid/sputum (45.1\%), saliva (42.7\%), and tears (34.8\%). The majority of the participating nurses (58.5\%) thought that foams/ sponges and diaphragms were prophylactics for HIV/AIDS (Table 3). One third believed that intrauterine contraceptive device and contraceptive pills also offered protection. Depending on the level of education of the nurses, the mean score for "knowledge regarding transmission and nontransmission of HIV"," presence of HIV in body fluids," and "prophylaxis provided through antibiotic prophylaxis methods" was not different according to the analysis of variance (ANOVA) test, but the mean overall knowledge was different (Table 4). The mean of the total knowledge of university-graduated nurses was higher than that of the high school-graduated nurses according to the post-ANOVA test [Tukey's honest significant difference (HSD)], and was found to be statistically significant $(P<0.05)$. Conversely, the differences between the nurses with associate education and their counterparts with undergraduate education ( $P=0.68$ ) and between the nurses with high school education and those with undergraduate education $(P=0.21)$ were not significant according to the Tukey's HSD test. No significant difference was found between the mean scores of the knowledge of nurses regarding AIDS depending on their educational level and professional experience $(P>0.05)$.

An almost moderate relationship existed between the fear of contagion and negative feelings ( $r=0.43)$, a weak relationship between fear of contagion and resistance, and a weak relationship between professional resistance and negative feelings $(r=0.29$ and 0.20 , respectively) (Table 5).
A poor inverse correlation was found with nurses' knowledge regarding HIV transmission ( $r=-0.20, P<0.05)$. If the nurses knew well enough how HIV spread, this inverse relationship would have been stronger. A direct relationship was found between the scores of nurses' knowledge regarding the body fluids in which HIV was present and their scores on HIV transmission ( $r=0.21$, $P<0.01)$. However, the relationship between their scores on transmission methods was inverse and poor $(r=-0.21, P<$ 0.01). No relationship was found between nurses'scores regarding which antibiotic prophylaxis methods provided protection for HIV/AIDS and their scores of attitudes toward HIV/AIDS and other knowledge scores (Table 5). The relationship between the overall scores of nurses' knowledge on HIV/AIDS and their scores on HIV transmission, and their subscale scores was rather poor (Table 5), indicating that nurses possessed incorrect knowledge regarding HIV transmission.

\section{DISCUSSION}

The levels of knowledge of nurses regarding HIV/AIDS and their attitudes toward PLWH at their workplaces in Yozgat State Hospital were assessed. The nurses were in the high-risk group for bloodborne diseases, such as hepatitis B and C and HIV/AIDS. Despite the protection provided by prophylactic measures, nurses might have insufficient knowledge, prejudice, and baseless fear while performing their jobs.

In this study, the mean scores of the nurses in the AIDS Attitude Scale and subscales (fear of contagion, professional resistance, and negative feelings) were more than the average (Table 2). The high mean score on the AIDS Attitude Scale indicated that nurses had assumed a negative attitude toward PLWH patients. These findings were consistent with those of previous studies (22). In a study on physicians with similar working conditions, the physicians, despite 
TABLE 3: Opinions held by nurses regarding HIV/AIDS transmission $(n=164)$.

\begin{tabular}{|c|c|c|c|}
\hline HIV/AIDS transmission & $\mathrm{n}(\%)$ & HIV/AIDS nontransmission & n (\%) \\
\hline Through blood and its products & $163(99.4)$ & $\begin{array}{l}\text { Shared use of objects, such as towels, } \\
\text { glasses, forks, and spoons }\end{array}$ & $135(82.3)$ \\
\hline Through tissue/organ transplant & $153(93.3)$ & Normal (dry) kissing & $146(89.0)$ \\
\hline Dentistry equipment & $137(83.5)$ & Hugging, touching, and handshaking & $132(80.5)$ \\
\hline $\begin{array}{l}\text { Minor surgical operations (including equipment of } \\
\text { circumcision) }\end{array}$ & $160(97.6)$ & Use of toilet (traditional/closet) & $125(76.2)$ \\
\hline Shared use of syringe & $160(97.6)$ & Mosquito/insect bite & $96(85.8)$ \\
\hline Barber equipment & $132(80.5)$ & Heredity & $30(18.3)$ \\
\hline Equipment for manicure/pedicure & 108 (65.9) & & \\
\hline Getting a tattoo & $99(60.4)$ & & \\
\hline Sexual intercourse without contraceptives & $150(91.5)$ & & \\
\hline Transmission from mother to fetus during pregnancy & 154 (93.9) & & \\
\hline Transmission from mother to baby through breastfeeding & $157(95.7)$ & & \\
\hline HIV-containing body fluids & & $\begin{array}{l}\text { AP methods effective in protection } \\
\text { from HIV/AIDS }\end{array}$ & \\
\hline Semen & $162(98.8)$ & Condom (D) & $154(93.38)$ \\
\hline Vaginal secretion & $161(98.2)$ & Foam/sponge/diaphragm (Y) & $68(41.5)$ \\
\hline Mother's milk & $146(89.0)$ & Intrauterine devices $(\mathrm{Y})$ & $108(65.9)$ \\
\hline Cerebrospinal fluid & $155(94.5)$ & Spermatocytes (Y) & $129(78.7)$ \\
\hline Saliva & $70(42.7)$ & Contraceptives (Y) & $109(66.5)$ \\
\hline Bronchial fluid (sputum) & $74(45.1)$ & Ligation of fallopian tubes $(\mathrm{Y})$ & $137(83.5)$ \\
\hline Urine & $102(62.2)$ & Withdrawal (Y) & $150(91.5)$ \\
\hline Tears & $57(34.8)$ & Calendar method & $156(95.1)$ \\
\hline
\end{tabular}

having sufficient knowledge regarding HIV/AIDS, still had anxieties (23). In the studies regarding the levels of knowledge of nurses on HIV/AIDS, the lack of knowledge and prejudice were thought to affect the fear of contagion and professional resistance $(8,13$, 16). Çimen et al. (2005) studied nursing students' attitudes toward HIV/AIDS and reported that the points obtained for the items on the scale and its subscales (fear of contagion, negative feeling, and professional resistance) were lower than the average point in the same study (20). Röndahl et al. (2003) reported that, if possible, $36 \%$ of the nurses in their study would rather not be responsible for the care of PLWH. Moreover, they found that nurses had greater negative attitudes compared with the nursing students toward PLWH (24). The study by Şahin et al. (2000) revealed that $82.6 \%$ of nurses considered themselves at risk of HIV infection, while 20.3\% believed that health care personnel should have the right to not intervene in PLWH (25).

Social relations and contacts are extremely important for PLWH. Many patients need to be enlightened about the situation they are in and talk to people from the health care team about the issue. However, health personnel have been reluctant to answer even innocent questions about daily life in PLWH. The feeling of discomfort increases especially in subjects involving sexuality.

Moreover, patient questions may not be perceived as questions because of nurses' daily burden of work, their responsibility to care for other patients, their negative attitudes, and their reluctance to assume responsibility regarding these issues. Thus, PLWH may benefit less from health care services. The findings from a study 
TABLE 4: Distribution of nurses knowledge regarding AIDS in relation to their educational levels.

\begin{tabular}{lccccc}
\hline Educational level & $\begin{array}{c}\text { Transmission score } \\
\mathrm{X} \pm \mathrm{SS}\end{array}$ & $\begin{array}{c}\text { Nontransmission score } \\
\mathrm{X} \pm \mathrm{SS}\end{array}$ & $\begin{array}{c}\text { Presence in } \\
\text { body liquids } \\
\mathrm{X} \pm \mathrm{SS}\end{array}$ & $\begin{array}{c}\text { Protectiveness of } \\
\text { AP methods } \\
\mathrm{X} \pm \mathrm{SS}\end{array}$ & $\begin{array}{c}\text { Overall score of } \\
\text { knowledge } \\
\mathrm{X} \pm \mathrm{SS}\end{array}$ \\
\hline $\begin{array}{l}\text { Vocational } \\
\text { high school }\end{array}$ & $4.5 \pm 1.4$ & $3.9 \pm 1.0$ & $5.4 \pm 1.5$ & $5.7 \pm 1.6$ & $24.5 \pm 2.5$ \\
Associate & $9.6 \pm 1.3$ & $4.1 \pm 1.1$ & $5.8 \pm 1.6$ & $6.4 \pm 1.5$ & $26.0 \pm 2.7$ \\
Undergraduate & $9.4 \pm 1.6$ & $4.1 \pm 1.3$ & $5.7 \pm 1.7$ & $6.3 \pm 1.6$ & $25.5 \pm 3.5$ \\
F, P & $0.4,0.69$ & $0.6,0.54$ & $1.1,0.35$ & $2.7,0.07$ & $3.7,0.03$ \\
X \pm SS & $9.5 \pm 1.4$ & $4.1 \pm 1.1$ & $5.6 \pm 1.6$ & $6.2 \pm 1.6$ & $25.4 \pm 2.9$ \\
Range & $5-11$ & $0-6$ & $2-8$ & $1-8$ & $19-32$ \\
\hline
\end{tabular}

conducted in Ankara by Duyan et al. (2001), in which they assessed physicians' attitudes toward PLWH, were consistent with those of the present study (23).

The educational level had an effect on the fear of contagion (22, $26,27)$. Nurses with higher education were more comfortable when providing care for PLWH (27). The mean scores of nurses in relation to their educational level in the ANOVA test, the knowledge of HIV transmission and nontransmission, the presence of HIV in body fluids, and the protection afforded by antibiotic prophylaxis methods did not differ, unlike their mean overall score (Table 3). Tukey's HSD revealed that the mean overall scores of the nurses with associate degrees were higher than the scores of their high school counterparts $(P<0.05)$. Conversely, the differences in scores between the nurses with associate degrees and those with undergraduate degrees $(P=0.68)$ and between high school graduates and those with undergraduate degrees $(P=0.21)$ were not significant $(P>0.05)$. The mean scores of nurses' knowledge on HIV/AIDS in relation to their marital status and the length of their professional experiences did not differ significantly ( $P>0.05)$. In another study, more than half of the nurses failed to provide correct answers to the questions intended to assess their knowledge of the means of HIV/AIDS transmission. Even if they were equipped with a basic knowledge of HIV/AIDS through their education, they might be under the influence of societal misjudgments and ambivalence. This finding was consistent with a previous study (21). In a study conducted in the Middle East, 81\% of nurses lacked HIV/AIDS knowledge regardless of their educational levels, and 96.5\% needed support to cope with their deficiencies. The attitude of the same group toward HIV/AIDS was reported as negative by approximately $85 \%$ (8).

A nearly moderate correlation was observed between the fear of HIV transmission and negative feelings subscales, whereas the correlations were weak between the fear of contagion and professional resistance and between professional resistance and negative feelings (Table 5). A weak, inverse correlation existed between nurses' knowledge of HIV transmission and their fear of contagion ( $P<0.05$ ). If the nurses sufficiently knew the ways in which HIV was not transmitted, this inverse relationship would be stronger. A weak direct correlation was found between the nurses' score of knowledge regarding which body fluids contained HIV $(P<0.01)$. Normally, these two relationships were stronger. No relationship was found between the scores of knowledge regarding which of the antibiotic prophylaxis methods were protective against HIV/AIDS, means of transmission, and presence of HIV in body fluids, and AIDS Attitude Scores and other knowledge scores (Table 4). Discrepancies existed between the nurses' knowledge of which antibiotic prophylaxis methods were protective against HIV/ AIDS, means of transmission, and presence of HIV in body fluids. The relationship between the nurses' overall score on the score of knowledge of HIV/AIDS and means of transmission subscale was rather weak (Table 4), indicating that nurses were misinformed about the means of HIV transmission. A direct relationship existed between sufficient information about HIV/AIDS and the implementation of protective measures. This finding was consistent with findings from previous studies (21). 
TABLE 5: Spearman's correlation between AIDS Attitude Score and knowledge score.

$N=164$

\section{Negative feelings}

Fear of contagion

Professional resistance

Overall AIDS attitude

Score of knowledge on

ways of transmission

Score of knowledge on the

ways of nontransmission

Overall score of knowledge on ways of transmission

Score of knowledge on the presence of HIV in bodily liquids

Score of knowledge on the protectiveness of antibiotic prophylaxis methods against AIDS

Overall score of AIDS

0,028

knowledge

1,000

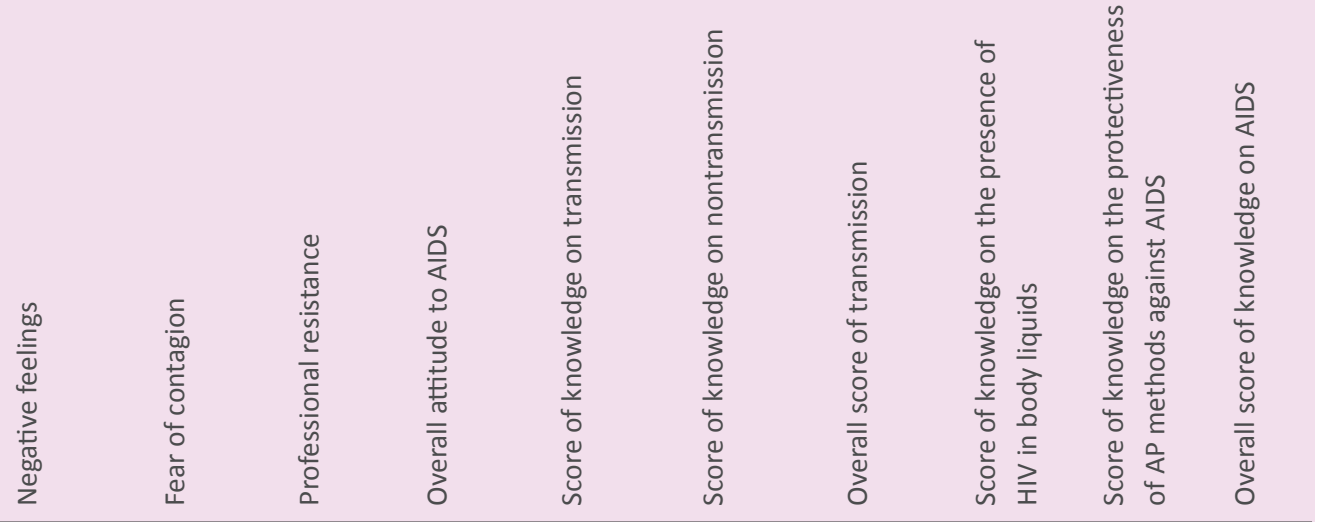

$0,426 * * \quad 1,000$

$0,203 * * \quad 0,287 * * \quad 1,000$

$0,665 * * \quad 0,782 * * \quad 0,679 * * \quad 1,000$

$\begin{array}{lllll}-0,024 & 0,027 & 0,014 & 0,033 & 1,000\end{array}$

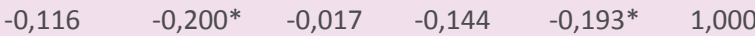

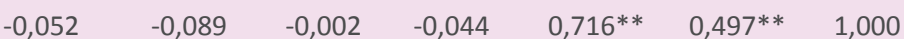

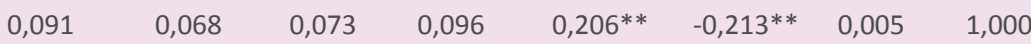

$\begin{array}{lllllllll}0,038 & 0,026 & 0,020 & 0,016 & 0,146 & 0,044 & 0,149 & 0,001 & 1,000\end{array}$

${ }^{*},{ }^{* *}$ Correlation is significant at the 0.05 level (2-tailed).

Studies have reported that nurses and health care workers possess inadequate and incorrect information about HIV/AIDS. More than half of the study participants reported that they considered refusing to assist PLWH. Nurses lack knowledge and skill regarding HIV/AIDS, leading to as much negative attitude toward the PLWH as the general people (28).

\section{CONCLUSIONS}

The nurses in this study were concerned about being infected with HIV, and generally held a negative attitude toward PLWH. The fear of contagion was found to correlate almost moderately with negative feelings, and was weakly correlated with professional resistance. Similarly, professional resistance was weakly correlated with negative feelings. The relationship between the levels of knowledge of nurses regarding HIV transmission and fear of contagion was inverse and weak. Nurses comprised the majority of health care workers and provided direct care for patients. Better patient care and minimization of unfavorable attitudes toward PLWH could be possible by increasing the levels of knowledge of nurses on HIV/AIDS. 


\section{REFERENCES}

1. Midilli K, İnsan bağışıklık yetmezliği virusu (HIV)'nun biyolojisi. Türkiye Klinikleri J Int Med Sci 2007; 3(28):1-6.

2. Babayıgıt MA, Bakır B. HIV enfeksiyonu ve AIDS: Epidemiyoloji ve korunma, TSK Koruyucu Hekimlik Bülteni 2004;3 (11).

3. Tümer A. Dünyada ve Türkiye'de güncel verilerle HIV/AIDS. Türk HIV AIDS Dergisi 2006; 9(4).

4. Ceylan E, Koç A. HIV(+) / AIDS hastalarında antiretroviral tedaviye uyumun önemi (Literatür Çalışması). Jinekoloji Obstetrik ve Neonatoloji Tıp Dergisi, 2017; 14(2): 64 - 71

5. Cichocki M 2007. HIV/AIDS in healthcare workers occupational exposure to HIV does occur (RetrivedFrom http://aids.about. com/od/dataandstatistics/qt/healthstats.htm> 10/01/2013).

6. Koç A. Klinikte hemşirelerin AIDS hastalarına karşı tutumları nedir? Anatol J Clin Investig 2014;8(1):28-32.

7. Altıok M, Kuyurtar F, Karaçorlu S, Ersöz G, Erdoğan S. Sağlık çalışanlarının delici kesici aletlerle yaralanma deneyimleri ve yaralanmaya yönelik alınan önlemler. Maltepe Üniversitesi Hemşirelik Bilim ve Sanatı Dergisi 2009;2(3).

8. Hassan ZM, Wahsheh MA. Knowledge and attitudes of jordanian nurses towards patients with HIV/AIDS: Findings from a Nationwide Survey. Issues in Mental Health Nursing 2011; 32 (12): 774-784.

9. Li L, Li Y, Zeng K, Wu Y. Knowledge and attitudes to HIV/AIDS in Chinese registered nurses. Zhong Nan Da Xue Bao Yi Xue Ban. 2011; 36(2):121-7.

10. Sherman DW. Experiences of AIDS-dedicated nurses in alleviating the stress of AIDS caregiving. Journal of Advanced Nursing 2000; 31(6): 1501-1508.

11. Hatipoğlu ÇA, Bulut C, Çelik AK, Yıldız F, Kınıklı S, Demiröz AP. Bir eğitim hastanesindeki sağlık personelinin HIV/AIDS konusundaki bilgi düzeyleri Türk HIV AIDS Dergisi 2005; 8(2) 56.

12. Tümer A. (2010) HIV/AIDS Epidemiyolojisi ve korunma. Hacettepe Üniversitesi HIV / AIDS Tedavi ve Araştırma Merkezi (HATAM). (Retrived from http://www.hatam. hacettepe.edu.tr/ Epid_web_10.pdf. 10.12.2012).

13. Timurkaynak $F$, Akgün $S$, Arslan $H$. Başkent üniversitesi hastanesinde görev yapan hemşirelerin aids hastalığı konusundaki bilgi ve tutumları üzerine bir araştırma. HIV\& AIDS 2001; 4(4): 123-130.

14. Suominen $T$, Koponen $N$, Mockiene $V$, et al. Nurses' and nursing students' perceptions of sexual risk behavior: a study in Finland, Estonia, and Lithuania. AIDS Patient Care STDS Oct 2008;22(10): 803-10.

15. Kalichman SC, Simbayi LC. HIV testing attitudes, AIDS stigma, and voluntary HIV counselling and testing in a black township in Cape Town, South Africa, Sex Transm Infect 2003; 79:442-447.
16. Badahdah AM. Stigmatization of Persons With HIV/AIDS in Saudi Arabia, Journal of Transcultural Nursing 2010; 21(4) 386- 392.

17. Serter D. Türkiye'de ve Dünyada cinsel yolla bulaşan enfeksiyonlar ve HIV/AIDS. Turkiye Klinikleri J Int Med Sci 2006;2(11):1-5

18. Yozgat V. (Retrieved from http://tr.wikipedia.org/wiki/Yozgat_ (il), Erişim tarihi 5/1/2013.

19. Bliwise NG, Grade M, Irish TM, Ficarrotto TJ. Measuring medical and students' attitudes toward AIDS. Health Psychology 1991 10(4): 289-295.

20. Çimen S, Bahar Z, Öztürk C, Bektaş M. AIDS tutum ölçeğinin geçerlik ve güvenirlik çalışması. Zonguldak Sağlık Yüksekokulu Sağlık Eğitim Araştırma Dergisi 2005;1(1):1-11.

21. Koç, A. Nurses' level of knowledge on the human immunodeficiency virus/acquired immune deficiency syndrome (HIV/AIDS), behavior and practices: A survey from Turkish Society. Journal of AIDS and HIV Research 2013; 5(2): 27-33.

22. Delobelle P, Rawlinson JL, Ntuli S, Malatsi I, Decock R, Depoorter AM., HIV/AIDS knowledge, attitudes, practices and perceptions of rural nurses in South Africa. Journal of Advanced Nursing 2009;65: 1061-1073.

23. Duyan V, Agalar F, Sayek, I. Surgeons' attitudes toward HIV/ AIDS in Turkey. AIDS Care 2001;13(2):243-250.

24. Röndahl G, Innala $S$, Carlsson M. Nursing staff and nursing students' attitudes towards HIV-infected and homosexual HIV-infected patients in Sweden and the wish to refrain from nursing. J Adv Nurs 2003;41(5):454-61.

25. Şahin TK, Kara F, Ural O. Selçuk Üniversitesi Tıp Fakültesi hastanesinde görevli hemşirelerin AIDS konusundaki bilgi ve tutumlarının değerlendirilmesi. Selçuk Üniversitesi Tıp Fakültesi Dergisi 2000;16(3):139-150.

26. Aisien AO, Shobowale MO. Health care workers' knowledge on HIV and AIDS: universal precautions and attitude towards PLWHA in Benin-City, Nigeria. Niger J Clin Pract. 2005;8(2):7482.

27. Martin JE, Bedimo AL. Nurse practitioner, nurse midwife and physician assistant attitudes and care practices related to persons with HIV/AIDS. Journal of the American Academy of Nurse Practitioners 2000;12(2):35-42.

28. Amosu AM, Degun AM, Makinde CM, Thomas AM, Babalola AO. An assessment of specific knowledge and attitude of healthcare providers towards people living with HIV/AIDS in Ibadan. Nigeria Annals of Biological Research 2011; 2 (2):255264. 